Article

\title{
Competition NMR for Detection of Hit/Lead Inhibitors of Protein-Protein Interactions
}

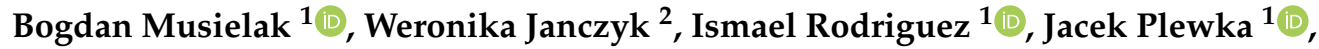 \\ Dominik Sala ${ }^{1}\left(\mathbb{D}\right.$, Katarzyna Magiera-Mularz ${ }^{1}$ (1) and Tad Holak ${ }^{1,2, *(1)}$
}

1 Department of Organic Chemistry, Faculty of Chemistry, Jagiellonian University, Gronostajowa 2, 30-387 Krakow, Poland; bogdan.musielak@uj.edu.pl (B.M.); ismael.rodriguez@doctoral.uj.edu.pl (I.R.); jacek.plewka@uj.edu.pl (J.P.); dominik.sala@doctoral.uj.edu.pl (D.S.); k.magiera@uj.edu.pl (K.M.-M.)

2 Max Planck Institute for Biochemistry, Am Klopferspitz 18, 82152 Martinsried, Germany; weronika.janczyk@gmail.com

* Correspondence: holak@chemia.uj.edu.pl

Academic Editor: Simona Golič Grdadolnik

Received: 17 June 2020; Accepted: 29 June 2020; Published: 1 July 2020

check for updates

\begin{abstract}
Screening for small-molecule fragments that can lead to potent inhibitors of protein-protein interactions (PPIs) is often a laborious step as the fragments cannot dissociate the targeted PPI due to their low $\mu \mathrm{M}-\mathrm{mM}$ affinities. Here, we describe an NMR competition assay called w-AIDA-NMR (weak-antagonist induced dissociation assay-NMR), which is sensitive to weak $\mu \mathrm{M}-\mathrm{mM}$ ligand-protein interactions and which can be used in initial fragment screening campaigns. By introducing point mutations in the complex's protein that is not targeted by the inhibitor, we lower the effective affinity of the complex, allowing for short fragments to dissociate the complex. We illustrate the method with the compounds that block the Mdm2/X-p53 and PD-1/PD-L1 oncogenic interactions. Targeting the PD-/PD-L1 PPI has profoundly advanced the treatment of different types of cancers.
\end{abstract}

Keywords: NMR; Mdm2/p53; PD-1/PD-L1; protein-protein interaction; small molecule

\section{Introduction}

NMR spectroscopy is a highly versatile screening method for drug discovery [1-3]. In comparison to other screening technologies, NMR is capable of detecting the binding of small-molecule compounds to macromolecular targets over an extraordinarily broad affinity range from covalent to millimolar $[4,5]$. A unique feature of NMR is its robust capability to detect weak intermolecular interactions. This feature makes NMR ideal for fragment-based screening in which the binary binding between low-affinity fragments and target proteins is studied [1-3,6-8]. This type of NMR "binary screening" does not provide information about whether a compound can inhibit or dissociate protein-protein interactions. We have recently described an NMR-based assay for studying the effect of antagonists on protein-protein interactions [9-13]. The method, named AIDA-NMR (for the antagonist induced dissociation assay-NMR), belongs to the target protein-detected NMR screening methods [14] and provides unambiguous information on whether an antagonist of a protein-protein interaction is strong enough to dissociate the complex. Whether a hit/lead compound is capable of dissociating a particular protein-protein interaction (PPI) is determined by the strength of its binding to one of the two protein components of the PPI. If the binding is comparable or stronger than the affinity of the protein-protein interaction, for which biologically relevant protein-protein interactions have $K_{D} s$ between low $n M$ (tight binding) and low $\mu \mathrm{M}$ (weak binding), the PPI complex should be broken up. The "weak" small-molecule binders to the proteins of the PPI, for example, those ligands with the $\mathrm{IC}_{50}$ in high $\mu \mathrm{M}$ and $\mathrm{mM}$ range, would not affect the AIDA-NMR (although there is, albeit weak, binding to one of the 
proteins of the PPI). Thus, the strength of the PPI complex determines the weakest binding compounds that may still be measured with the AIDA-NMR.

Herein, we describe an AIDA-NMR technology that should overcome these disadvantages, allowing for NMR to be used in the primary fragment screening. We use the Mdm2-p53 and MdmX-p53 interactions [15,16] as proof-of-concept systems to develop our protocol and use the method on the immune oncology system of the PD-1/PD-L1 interaction $[17,18]$.

The tumor suppressor $\mathrm{p} 53$ protein is a key player in protecting the organism from cancer and was therefore given the term "the guardian of the genome". To escape the control system mediated by p53, the majority of human cancers has either mutation within p53 (50\% all cancers), whereas the rest compromises the effectiveness of the p53 pathway $[19,20]$. In tumors with unmodified wildtype p53, the p53 pathway is inactivated by the Mdm2 and MdmX proteins [21,22]. Therefore, the disruption of the Mdm2-p53/MdmX-p53 interactions that leads to the restoration of the impaired function of p53 poses a new approach to anticancer therapies across a broad spectrum of cancers.

Another important protein target in cancer is the PD-1/PD-L1 system. PD-1 (programmed cell death protein 1) is expressed on activated T cells and plays a critical role in modulation of the host's immune response [23,24]. The principal PD-1 ligand, PD-L1, is expressed on macrophages, monocytes, and cancer cells. Cancer cells exploit this ligand protein to avoid immune attack by $\mathrm{T}$ cells [25]. This seminal finding of how cancer cells use binding between PD-L1 and PD-1 to inhibit the killing of tumor cells by $\mathrm{T}$ cell has now been translated into effective medical treatment $[17,26-30]$. Blocking the immune checkpoint PD-L1 or PD-1 allows for the T cell killing of tumor cells, and immune checkpoint inhibitors targeting the PD-1/PD-L1 interaction have revolutionized modern cancer therapy for advanced cancer [18,31-33].

The interaction of PD-L1/PD-1 and $\mathrm{p} 53-\mathrm{Mdm} 2 / \mathrm{X}$ presents challenging cases in detecting weak binders, because the $K_{D}$ of this interaction is 8.2 and $0.2-0.6 \mu \mathrm{M}$, respectively [34,35]. We show herein that by introducing designed mutations in the component protein(s) of these protein-protein complexes, we could weaken the affinity of the PPI interaction. The mutations are introduced within the binding partner that is not targeted with inhibitors, therefore not compromising the binding interface of targeted protein and tested ligand. For example, in the case of the p53/Mdm2 complex, we mutated p53 to determine fragments binding to Mdm2 that dissociates the complex. Since there are over 30,000 known naturally occurring missense mutations to p53 [36,37], such a system is physiologically still relevant. Mutations within the non-targeted binding partner allow for the proteins that build up the PPI complex to be sensitive to weak binding compounds, i.e., the modified assay can be used in the fragment-based screening. We named this variant of the AIDA experiment "w-AIDA-NMR", where " $w$ " stands for "weak".

\section{Results}

\section{1. $p 53$ Mutants}

The complexes of wt-p53 with Mdm2 and MdmX have $K_{D}$ values $0.60 \mu \mathrm{M}$ and $0.24 \mu \mathrm{M}$, respectively [35]. These $\mathrm{K}_{\mathrm{D}}$ 's determine the weakest inhibitor, which can be tested with the AIDA-NMR methods. For the compounds that weakly bind to $\mathrm{Mdm} 2 / \mathrm{X}$, which still could be good initial scaffolds for further optimization in drug development processes, the method would not be sensitive enough for detecting inhibition of the p53-Mdm2 and p53-MdmX PPI.

Three key residues, namely Phe19, Trp23, and Leu26, of p53 make the highest contribution to the binding energy of p53 with Mdm2/X [38-40]. Among them, Trp23 is the most important, and any mutations of this residue completely abrogate the binding between p53 and Mdm2/X [39]. Mutations of Phe19 have similar effects, but they are not as strong as those of Trp23. Both residues are essential for $\mathrm{p} 53 / \mathrm{Mdm} 2$ complex formation. They are buried within pockets of $\mathrm{Mdm} 2 / \mathrm{X}$ with strong $\pi-\pi$ stabilizing interactions (Figure 1a,b; Supplementary Figure S1) [39]. Since the aim of the research was not to block the interaction but only to slightly weaken it, Phe19 and Trp23 were not touched, and Leu22 and Leu26 
were chosen as the most plausible targets of the mutations (Figure 1a,b; Supplementary Figure S1). In both Mdm2 and MdmX complexes with p53, the side chains of Leu22 and Leu26 were pointing to the outside of the main pocket occupied by Trp23 and Phe19 and had little effect on the structural arrangements of the p53-binding pockets of $\mathrm{Mdm} 2 / \mathrm{X}$, making them ideal candidates for our w-AIDA assay $[38,40,41]$ (Figure 1a,b and Supplementary Figure S1).

a

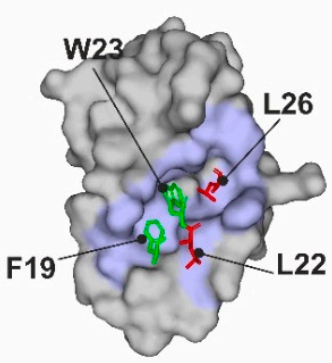

b

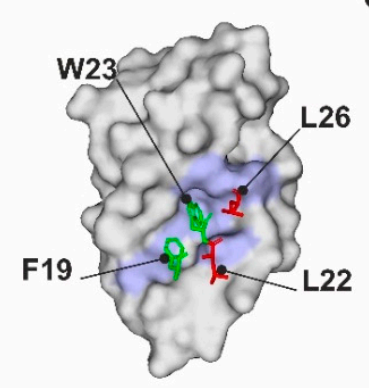

C

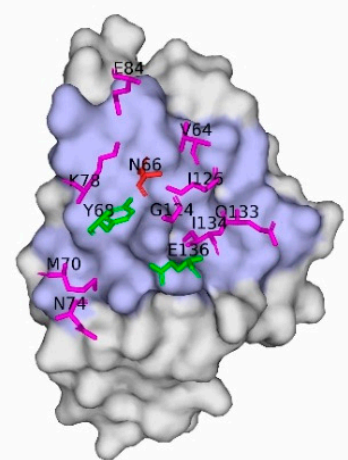

Figure 1. Visualization of the p53/Mdm2 (a), p53/MdmX (b), and PD-1/PD-L1 (c) complexes (PDB IDs:1YCR, 3DAB, and 4ZQK, respectively). The surface representation of Mdm2, MdmX, and PD-L1 is shown in gray with their interfaces with $\mathrm{p} 53$ and PD-1 in pale blue. For better visibility of the interfaces, p53 peptide is fully depicted as a cartoon, while only PD-1 residues crucial for interactions are shown. Interacting residues from p53 and PD-1 are shown as sticks with purple ones interacting with binding partners but not being essential for the interactions, green being residues whose mutation abolishes the interactions, and red being amino acids that were mutated within this manuscript consideration.

Taken together, these small changes in the p53 sequence should result in shortening of the side chain $(\mathrm{L} \rightarrow \mathrm{A}, \mathrm{L} \rightarrow \mathrm{V})$ or changing of the amino acids isoform $(\mathrm{L} \rightarrow \mathrm{I})$. $\mathrm{K}_{\mathrm{D}}$ values for the complexes of $\mathrm{Mdm} 2 / \mathrm{X}$ with the p53 mutants were established with isothermal titration calorimetry (ITC) (Table 1, Supplementary Figures S2-S8).

Table 1. Dissociation equilibrium constants of p53-wt and p53 mutants with $\mathrm{Mdm} 2$ and $\mathrm{MdmX}$ determined using ITC. Fitted curves are shown in Supplementary Figures S2-S8.

\begin{tabular}{ccc}
\hline Mutation of $\mathbf{p 5 3}$ & $\mathbf{M d m} \mathbf{( \mu \mathbf { M } )}$ & $\mathbf{M d m X}(\boldsymbol{\mu M})$ \\
\hline WT & $0.60 \pm 0.02$ & $0.24 \pm 0.02$ \\
L22A & $3.75 \pm 0.05$ & $1.54 \pm 0.03$ \\
L22I & $1.34 \pm 0.01$ & $0.39 \pm 0.03$ \\
L22V & $1.37 \pm 0.07$ & $0.86 \pm 0.02$ \\
L26I & $0.31 \pm 0.02$ & $0.32 \pm 0.02$ \\
L26V & $1.78 \pm 0.12$ & $0.60 \pm 0.04$ \\
L22IL26V & $3.00 \pm 0.02$ & $2.86 \pm 0.04$ \\
L22VL26V & $3.95 \pm 0.10$ & $4.64 \pm 0.26$ \\
\hline
\end{tabular}

The most significant lowering of the Mdm2/X-p53 interaction was observed for the L22A mutation, where the $K_{D}$ value increased six fold compared to that of the p53-wt/Mdm2 complex. Surprisingly, modifications of Leu26, which is one of the key amino acids of the p53 binding to Mdm2/X, were less efficient than mutations of Leu22. Moreover, the L26I mutant generated a lower $\mathrm{K}_{\mathrm{D}}$ value $(0.31 \mu \mathrm{M})$ than in the Mdm2/p53-wt interaction $(0.60 \mu \mathrm{M})$. Although the interaction with the L26V mutant was weakened, the affinities of the proteins were still too strong to use the preformed complexes for the investigation of the weak binding compounds. Therefore, we designed the double mutants (L22IL26V and L22VL26V), which combined the above-mentioned mutations. The ITC measurements showed a synergistic effect of the double mutations on the binding of the mutant $\mathrm{p} 53 \mathrm{~s}$ to $\mathrm{Mdm} 2 / \mathrm{X}$ (Supplementary Figures S7 and S8). One-dimensional proton NMR spectra of all mutants were almost 
identical to that of the wt-p53 spectra. This indicated that the mutated p53 constructs were correctly folded (data not shown).

\subsection{Inhibitors of the $w t-p 53 / M d m 2$ and wt-p53/MdmX Interactions}

A large number of low-molecular-weight compounds that bind to Mdm2 and MdmX [42-44] have been tested in clinical trials for several years [45,46]. Among the most advanced are cis-imidazoline derivatives called nutlins [47]. Nutlin-3a is a selective and potent inhibitor of the p53-Mdm2 interaction. The nutlin-3a derivative, idasanutlin, is currently under investigation in trials involving patients with advanced-stage hematological malignancies or solid tumors [48].

Three representative and well-studied small-molecule inhibitors of the wt-p53/Mdm2 interaction [49] (Figure 2) and three for the wt-p53/MdmX [50] (Figure 3) were chosen to test their inhibition of the following complexes: the wt-p53/Mdm2, mutant-p53/Mdm2, wt-p53/MdmX, and mutant-p53/MdmX.

WT
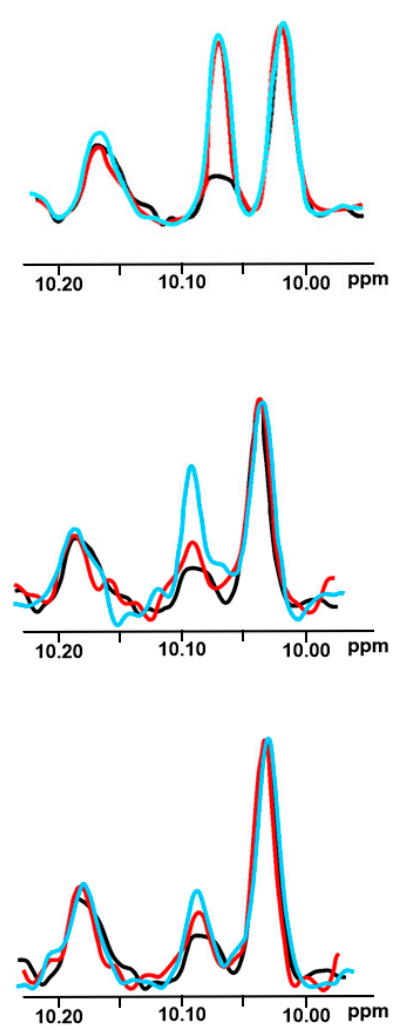
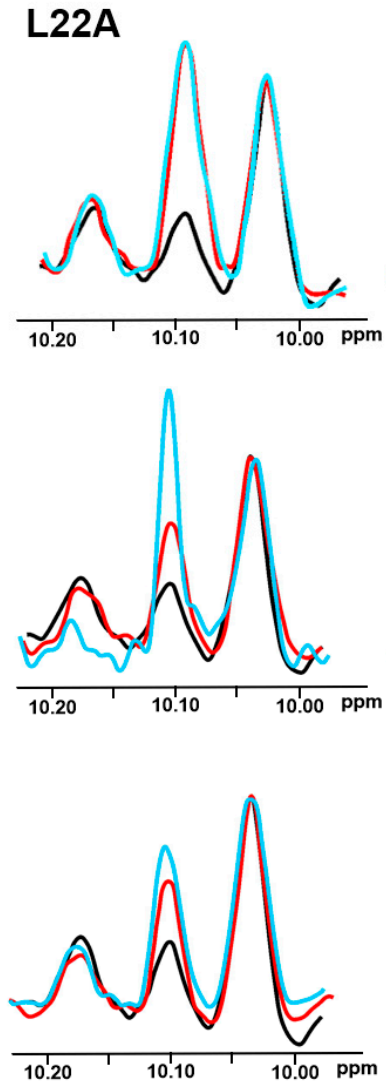

L22IL26V
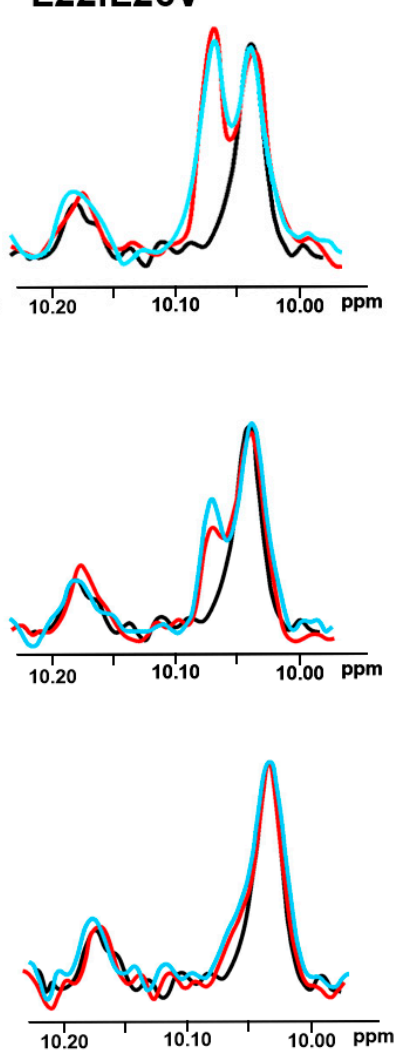

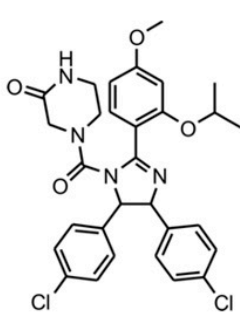

Nutlin-3a $K_{i}=0.09 \mu \mathrm{M}$
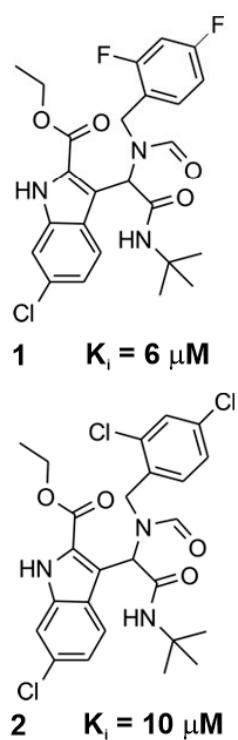

Figure 2. The 1D AIDA proton NMR spectra of the side chain ${ }^{\mathrm{N}} \mathrm{H}^{\varepsilon}$ protons of tryptophans for the p53/Mdm2 complexes (p53-wt, L22A, and L22IL26V). All protein complexes (black) were treated with Nutlin-3a, compounds 1 and 2 in molar ratio: the protein to a compound 1:1 (red) and 1:2 (blue), respectively. 
WT
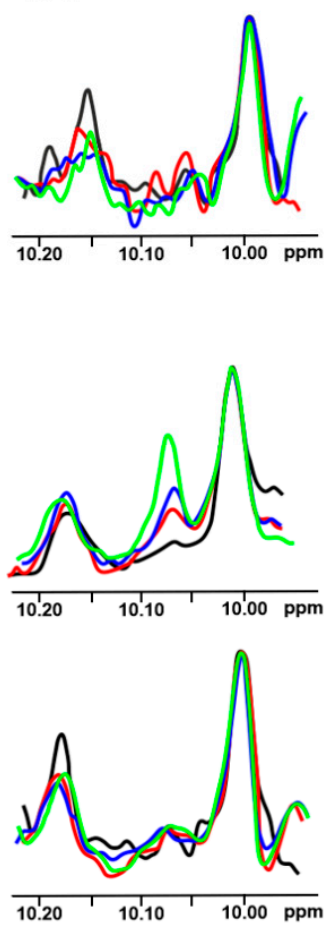

L22A

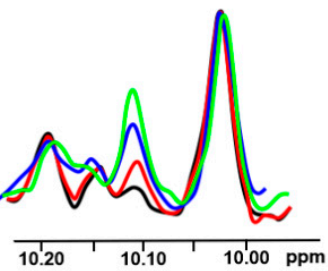

L22IL26V
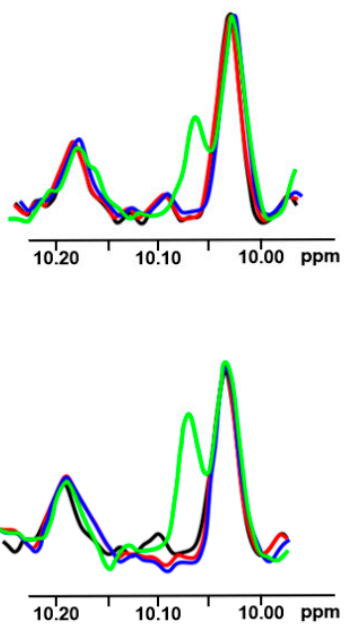
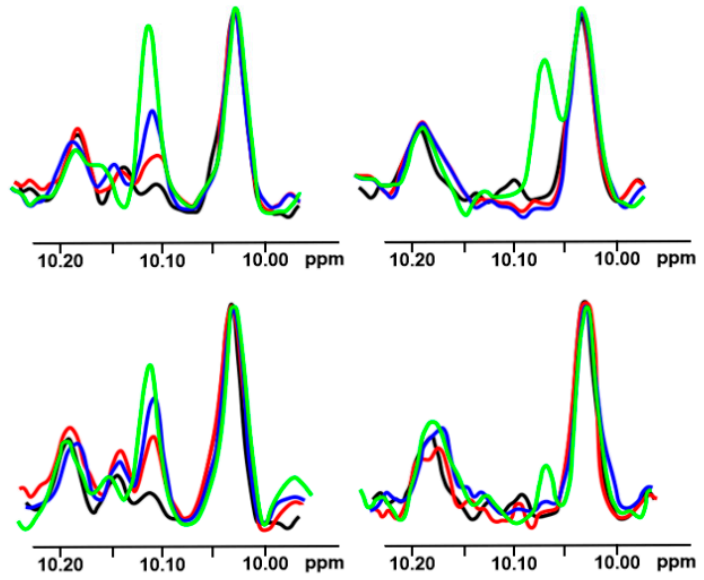

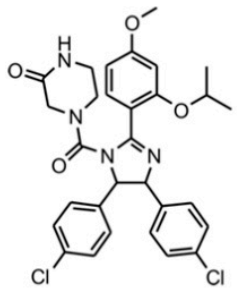

Nutlin-3a $\quad K_{i}=20 \mu M$
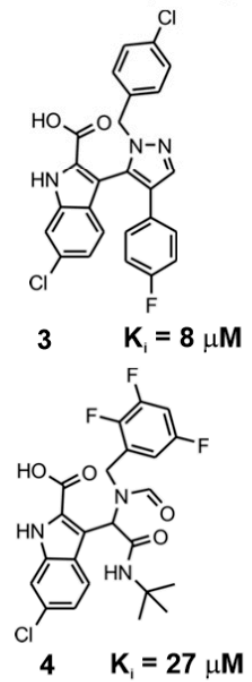

Figure 3. The 1D AIDA proton NMR spectra of the side chain ${ }^{\mathrm{N}} \mathrm{H}^{\varepsilon}$ proton of tryptophans for the mutant-p53/MdmX complexes (p53-wt, L22A, and L22IL26V). All protein complexes (black) were treated with Nutlin-3a, compound 3 and 4 in molar ratio: the protein to a compound 1:1 (red), 1:2 (blue), and 1:5 (green), respectively.

\subsection{AIDA-NMR for the wt-p53/Mdm2 and wt-p53/MdmX Complexes}

The AIDA-NMR assay, in its $1 \mathrm{D}^{1} \mathrm{H}-\mathrm{NMR}$ version $[13,14,51]$, was carried out with all selected compounds on the wt-p53 complexes. The 1D AIDA NMR experiment was based on monitoring the recovery of the signal of the ${ }^{\mathrm{N}} \mathrm{H}^{\varepsilon}$ proton of Trp23 upon addition of an inhibitor (Supplementary Figure S9) $[13,14,51]$. The full recovery of this signal was not observed for these five inhibitors even with the five-fold molar excess of the compound over the protein complexes. Only two inhibitors, namely $1\left(\mathrm{~K}_{\mathrm{i}}\right.$ value $6 \mu \mathrm{M}$ towards $\left.\mathrm{Mdm} 2\right)$ and $3\left(\mathrm{~K}_{\mathrm{i}}\right.$ value $8 \mu \mathrm{M}$ towards $\left.\mathrm{MdmX}\right)$, showed some weak interactions (Supplementary Figure S10). This means that the $K_{i}$ values of tested compounds were too high, and the method that used wt-p53 was not sensitive enough for monitoring these weaker binders to $\mathrm{Mdm} 2 / \mathrm{X}$.

\section{4. $w$-AIDA-NMR for the $p 53 / M d m 2$ and $p 53 / M d m X$ Complexes}

To choose proper mutants for the 1D NMR w-AIDA assay, we recorded ${ }^{1} \mathrm{H}$ NMR spectra of the all designed mutants (Figure 4). Since the 1D AIDA NMR experiment was based on the observation of the recovery of the signal of Trp23 upon addition of an inhibitor (Supplementary Figure S9) [13,14,51], it was crucial that the change in the position of that signal did not lead to it being obscured by overlapping with other signals. Although the introduced mutations were not significant for the overall protein structure, small changes in the local magnetic environment of Trp23 could be observed. These changes resulted in a slight shift of a position of the NMR signal corresponding to the ${ }^{N} \mathrm{H}^{\varepsilon}$ proton of Trp23 (L22A, L22I), partial overlapping (L22V, L26V, L22IL26V), or even the complete overlapping of the Trp23 with Trp53 signals (L22VL26V). 


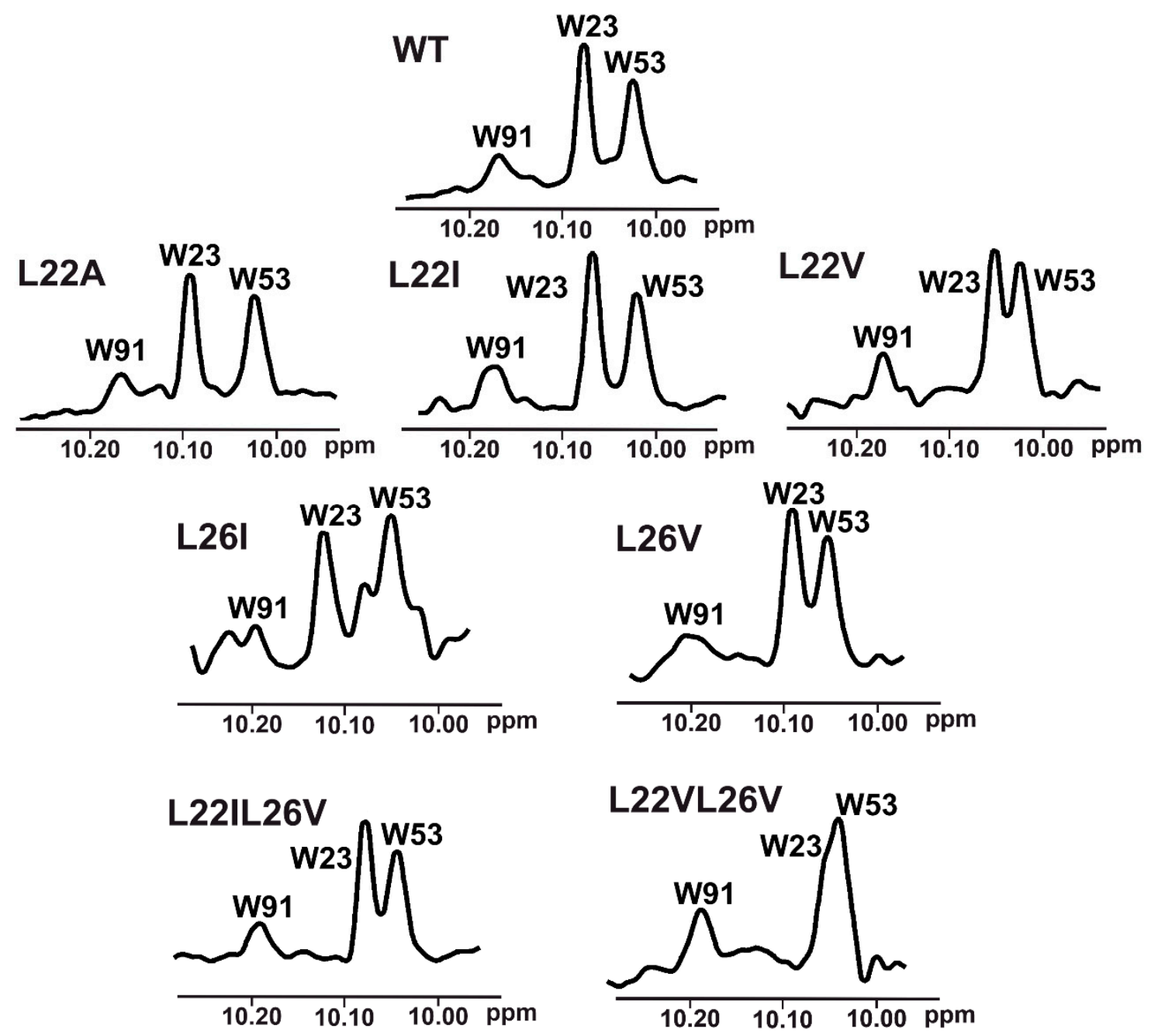

Figure 4. An enlarged part of the ${ }^{1} \mathrm{H}-\mathrm{NMR}$ spectrum of wt-p53 and its mutants. Visible peaks originate from the side chain ${ }^{{ }^{N}} \mathrm{H}^{\varepsilon}$ protons of W91, W23, and W53 left to right, respectively.

Based on the affinities determined with the ITC experiments (Supplementary Table S1 and Supplementary Figures S2-S8), as well as ${ }^{1} \mathrm{H}$ NMR spectra of the mutants (Figure 4), the L22IL26V and L22A mutants were chosen for evaluating their application in the ${ }^{1} \mathrm{H} \mathrm{w}$-AIDA-NMR assay. Application of mutants L22A and L22IL26V increased the sensitivity of the 1D AIDA-NMR assay. The Mdm2 inhibitors 1 and $\mathbf{2}$ caused almost full recovery of the Trp23 signal with the L22A mutant (Figure 2). For MdmX, all tested MdmX inhibitors released the p53 from its complex with MdmX (Figure 3). Better results were obtained for the L22A mutant than for the L22IL26V mutant.

\subsection{PD-1 Mutants}

The second PPI that we tested with the w-AIDA-NMR was the interaction of human PD-L1 with PD-1. Here we used the entire ectodomain of PD-1 and the PD-1 binding domain of the ectodomain of PD-L1 (residues 18-134) (Supplementary Figure S11). Although the PD-1/PD-L1 complex was characterized by a relatively high affinity constant around $8 \mu \mathrm{M}$ (Supplementary Figure S12), it was, nevertheless, too strong to be used in the NMR screening of "weak" fragments, which usually had two or three orders of magnitude lower affinities. Therefore, we designed a series of the PD-1 mutants based on the structure of the PD-1/PD-L1 complex [52]. We identified the amino acid candidates on PD-1 for the mutations using the same approach as that described for the p53/Mdm2/MdmX systems. The mutations should have weakened the binding of PD-1 to PD-L1 in a minimally invasive manner 
(Figure 1c, Supplementary Figures S1 and S13). The mutated PD-1 N66A, Y68A, E135A, and the double mutant N66AY68A were then expressed in E. coli (Supplementary Table S1) and checked by NMR whether the mutations affected the folding of the protein. From these tested mutants, only the N66A mutant was folded (the data for the other mutants not shown). Protein melting analysis showed that the N66A PD-1 mutant had a similar midpoint of thermal transition (melting temperature), indicating that the changes in its stability against denaturation were insignificant; in fact, the N66A mutant was slightly more temperature stable than wt-PD-1 (Supplementary Figure S14). The affinities of the PD-1/PD-L1 and (N66A)PD-1/PD-L1 complexes were determined using microscale thermophoresis by titrating the labeled PD-1 with the unlabeled PD-L1. The resulting data was next fitted with $\mathrm{K}_{\mathrm{D}}$ models to yield affinities. For the (N66A)PD-1/PD-L1 complex, we were not able to reach the top plateau as we could not concentrate PD-L1 solution above $183 \mu \mathrm{M}$ (Supplementary Figure S12). Therefore, the $\mathrm{K}_{\mathrm{D}}$ was estimated to be above $100 \mu \mathrm{M}$, considerably higher than for the native complex, allowing weaker small-molecular fragments to dissociate it. The N66A mutation did not affect the overall structure of the interface of the PD-1/PD-L1 complex as depicted in the Supplementary Figure S13. Asn66 is only involved in one hydrogen bond with Ala121 from PD-L1 and when mutated to alanine does not significantly change the space in the complex (Supplementary Figure S13 inset). Moreover, when overlaid on top of each other, the hPD-L1 residues that are critical for the interactions were virtually in the same position regardless of the mutations of PD-1, including murine PD-1-human PD-L1 complex (Supplementary Figure S13).

\subsection{Inhibitors of the Immunocheckpoint PD-1/PD-L1 Interaction}

A sizeable number of small-molecule binders to PD-L1 that inhibit this PPI has now been described (ca. 1000) [53,54]. We have recently published a series of studies on the affinities of the small-molecule inhibitors of the PD-1/PD-L1 interaction developed by Bristol-Myers Squibb (called herein the BMS compounds [55,56]). The BMS compounds are based on the hydrophobic biphenyl core scaffold [53,57]. Our NMR studies indicate that the binding of the BMS compounds to PD-L1 induces oligomerization of the protein [57-59]. The line width broadening in the NMR signals of PD-L1 after addition of BMS compounds, both in protons and ${ }^{1} \mathrm{H}^{-15} \mathrm{~N} 2 \mathrm{D} \mathrm{HMQCs}$, is so extensive that it is impossible to estimate dissociation constants also for "weaker" binding precursors of the BMS compounds (K $\mathrm{D}_{\mathrm{D}}$ 's double digit $\mu \mathrm{M})$. One of the NMR techniques that would allow validating the binding and estimating the value of $\mathrm{K}_{\mathrm{D}}$ is the $\mathrm{w}$-AIDA-NMR assay.

For the start in the PD-1/PD-L1 system, we used the two smallest fragments of the BMS-1166 inhibitor (fragments 5 and 6 in Supplementary Figure S15) [59]. BMS-1166 is one of the most potent small-molecule ICB inhibitors for the PD-1/PD-L1 developed until now [53]. It binds to PD-L1 and efficiently dissociates the human PD-1/PD-L1 complex in vitro [59]. In the ICB cell models, it activates the effector T cells, which are attenuated by both soluble and membrane-bound PD-L1 presented by antigen-presenting cells [59].

For the start in the PD-1/PD-L1 system, we used the two smallest fragments of the BMS-1166 inhibitor (fragments 5 and $\mathbf{6}$ in Supplementary Figure S15) that in our previous tests showed the interaction with the PD-L1 protein in the ${ }^{1} \mathrm{H}-{ }^{15} \mathrm{~N}$ HMQC NMR [59]. To perform the 2D AIDA experiment for 5 and $\mathbf{6}$, as the so-called reporter protein, which had to be ${ }^{15} \mathrm{~N}$ isotopically labeled, we used the ${ }^{15} \mathrm{~N}$-labeled PD-1 (13.2 kDa) (Supplementary Figure S16a). After addition of PD-L1 (14.9 kDa) in the molar ratio 1:1, most of the cross-peaks in the ${ }^{1} \mathrm{H}_{-}{ }^{15} \mathrm{~N}$ HMQC spectrum of PD-1 became broader, their intensities decreased, and most of the cross peaks disappeared (Supplementary Figure S16b). This result confirmed the forming of the complex with the molecular weight ca. $30 \mathrm{kDa}$. The AIDA-NMR assay was then applied to test the dissociating capabilities of $\mathbf{5}$ and $\mathbf{6}$. The compounds, despite being "active" in the binary interaction with PD-L1, were "inactive" in the AIDA test. No recovery signals from the ${ }^{15} \mathrm{~N}$ labeled PD-1 protein were observed in 2D and 1D spectra (Supplementary Figures S16c, d and S17). This shows that the tested compounds were not able to dissociate the PD-1/PD-L1 complex; their dissociation constants with PD-L1 were higher than the dissociation constant of the native human 
PD-1/PD-L1 complex (8 $\mu \mathrm{M}$; Supplementary Figure S12). We also performed a positive control, and the full recovery of the 2D HMQC spectrum of the ${ }^{15} \mathrm{~N}$ PD-1 was observed after adding BMS-1166 with $\mathrm{K}_{\mathrm{D}}=1.4 \mathrm{nM}$ to the sample with compound 5 (Supplementary Figure S16e).

\section{7. $w$-AIDA-NMR for the (N66A)PD-1/PD-L1 Complex}

In the same way as for the wt-PD-1 proteins, we performed a 2D AIDA-NMR experiment using the ${ }^{15} \mathrm{~N}$-labeled mutated proteins (N66A)PD-1 (13.2 kDa) and wt-PD-L1 (Figure 5a,b). In contrast to the pervious experiment, the resulting complex of the (N66A)PD-1/PD-L1 proteins (28.1 kDa) had a smaller number of broadening/disappearing signals in the HMQC spectra due to the higher $\mathrm{K}_{\mathrm{D}}$ value. However, most noticeable changes of the chemical shifts could be observed in the range ca. 8.8-9.4 and 122-127 ppm for hydrogen and nitrogen, respectively (Figure 5b). Addition of an equimolar amount of $\mathbf{5}$ or $\mathbf{6}$ resulted in dissociating of the PD-1/PD-L1 complex (Figure 5 c,d) with appreciable recovery of the $2 \mathrm{D}$ signals observed for 5 . This suggests that the fragment $\mathbf{6}$ is less potent than $\mathbf{5}$ despite the addition of the aromatic system. Next, for a positive control, to the sample of $\mathbf{6}$ an equimolar amount of BMS-1166 was added, and a full recovery of 2D HMQC spectrum of the ${ }^{15} \mathrm{~N}$ PD-1 was observed.

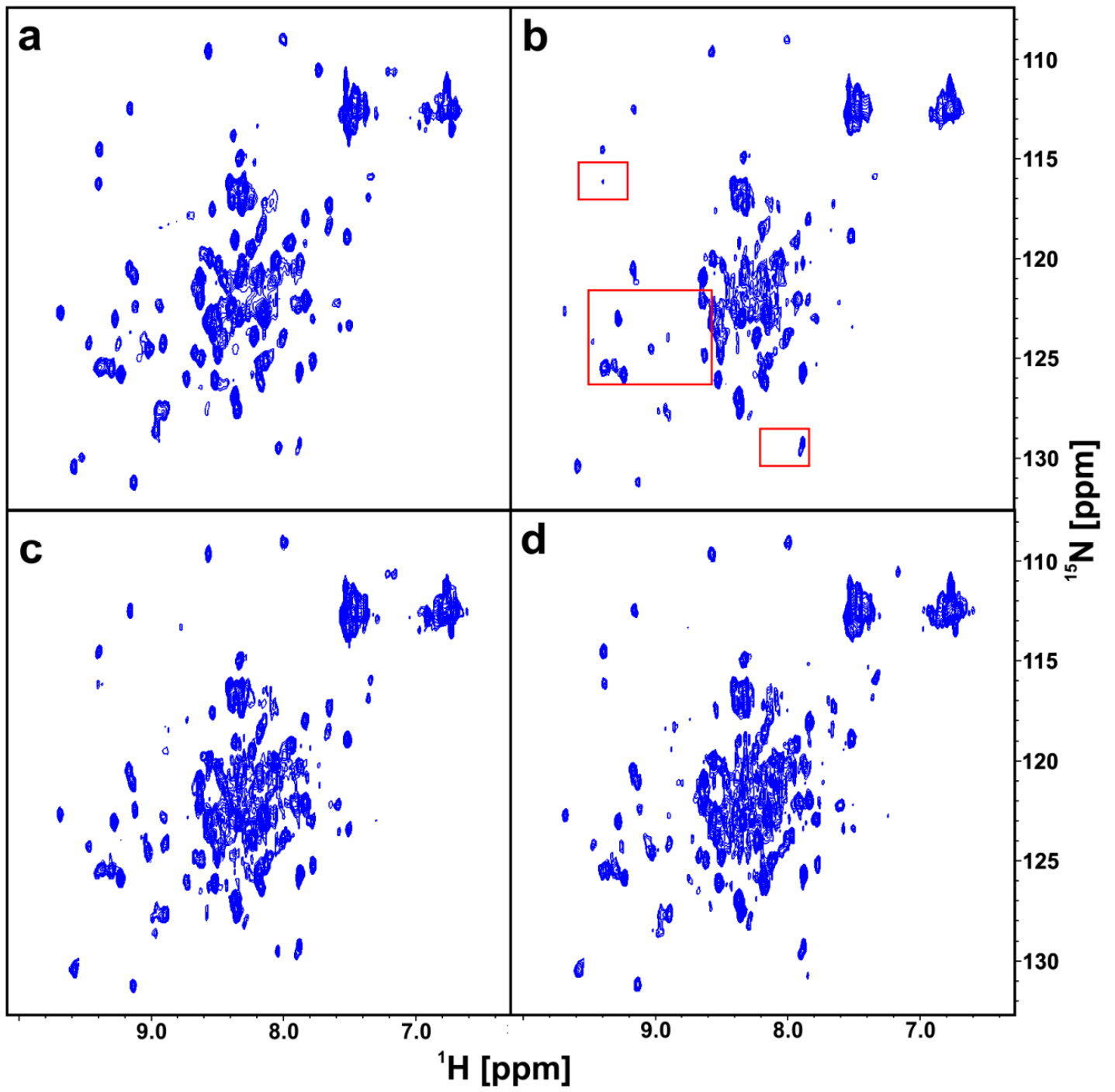

Figure 5. The 2D AIDA NMR for the mutant-PD-1/PD-L1 complexes. The spectra of apo-(N66A)PD-1 (a), the complex of (N66A)PD-1/PD-L1 with marked frames in red the most changing parts of the spectrum (b), the complex of (N66A)PD-1/PD-L1 with 5 (c), and $\mathbf{6}$ (d) in the molar ratio of the protein complex to the compound 1:1, respectively. 
Similar results can also be obtained by analyzing the $1 \mathrm{D}{ }^{1} \mathrm{H}-\mathrm{NMR}$ spectra (Supplementary Figure S18). As a result of the complex formation, significant signal broadening of the spectral lines could be observed. This was clearly visible for the NMR signals of PD-1 with the chemical shifts at -0.2 and $-0.7 \mathrm{ppm}$. After addition of the tested compounds, those signals partially recovered and significant sharpening of signals between 0.0 and $-0.1 \mathrm{ppm}$ were observed. The full recovery of the PD-1 signals was observed only after addition of BMS-1166.

We could estimate the dissociation constant of the PD-L1/fragment 5 interaction, which was in the range of $50 \pm 20 \mu \mathrm{M}$. In the case of fragment 6 , for which the $\mathrm{w}$-AIDA-NMR indicated less recovery of the NMR signals, we determined that the $K_{D}$ was around $120 \pm 40 \mu \mathrm{M}$ (the intensities of the recovered resonances are used to obtain an approximate dissociation constant. Errors are quantified from signal-to-noise in NMR spectra). These results correlated with the homogeneous time-resolved fluorescence (HTRF) assay, where the $\mathrm{IC}_{50^{\prime}} \mathrm{s}$ for 5 and 6 were determined at $34 \mu \mathrm{M}$ and above $100 \mu \mathrm{M}$, respectively (Supplementary Figure S19).

\subsection{AIDA-NMR on the Complex between wt-PD-1 and wt-PD-L1-Long}

The $\mathrm{K}_{\mathrm{D}}$ of the interaction of PD-1 with the construct of PD-L1 that encompassed amino acids 18-239 (PD-L1-Long, 24.3 kDa), was 51 MM (Supplementary Figure S11). The wt-PD-1/wt-PD-L1-Long interaction constitutes an example of detecting weak double digit $\mu \mathrm{M}$ to $\mathrm{mM}$ binders with the AIDA-NMR on the natively occurring protein-protein interactions.

For the wt-PD-1/wt-PD-L1-Long, we used the smallest fragment of BMS-1166, fragment 5, and tested its dissociating capability for this particular complex (Supplementary Figure S20). Fragment 5 dissociated the protein complexes, as suggested by the $\mathrm{K}_{\mathrm{D}}$ of the PPI, and in full agreement with the corresponding data for the w-AIDA-NMR of the mutant N66A of the shorter construct of PD-L1. The PD-1/PD-L1 complex of the latter was more stable in NMR conditions and therefore preferable in the AIDA-NMR experimental settings.

\section{Materials and Methods}

\subsection{Purification of $M d m 2$}

The recombinant human Mdm2 (1-125 aa) were cloned into pET11a vector (Novagen, Medison, WI, USA)) and expressed in E. coli BL21 (DE3) RIL (Invitrogen, Poland). Cells were grown at $37^{\circ} \mathrm{C}$, induced at $\mathrm{OD}_{600}$ of 0.6 with $1 \mathrm{mM}$ IPTG and left for expression for additional $4 \mathrm{~h}$ at $37^{\circ} \mathrm{C}$. Cells were harvested by centrifugation, and the protein was purified from inclusion bodies according to previously described methods [13]. The pellet was resuspended in PBS buffer and sonicated using a macrotip (output control 8, 80\%) 5 times for $2 \mathrm{~min}$. Lysate was then clarified by centrifugation at $60,000 \times g$ for $30 \mathrm{~min}$ at $4{ }^{\circ} \mathrm{C}$. Inclusion bodies were washed twice with PBS supplied with $0.05 \%$ TritonX-100 and centrifuged at $12,000 \times \mathrm{g}$ for $25 \mathrm{~min}$. They were later solubilized overnight in $6 \mathrm{M}$ guanidinium hydrochloride, $100 \mathrm{mM}$ Tris- $\mathrm{HCl}, \mathrm{pH} 8.0$, with the addition of $1 \mathrm{mM}$ EDTA, and $10 \mathrm{mM}$ $\beta$-mercaptoethanol at $37^{\circ} \mathrm{C}$. Solubilized inclusion bodies were next centrifuged at $60,000 \times g$ for 45 min at $4{ }^{\circ} \mathrm{C}$, and the resulting supernatant was dialyzed against $4 \mathrm{M}$ guanidinium hydrochloride, $\mathrm{pH} 3.5,10 \mathrm{mM} \beta$-mercaptoethanol for $6 \mathrm{~h}$. Refolding was performed in $10 \mathrm{mM}$ Tris- $\mathrm{HCl}, \mathrm{pH} \mathrm{7.0,}$ including $1 \mathrm{mM}$ EDTA and $10 \mathrm{mM} \beta$-mercaptoethanol at $4{ }^{\circ} \mathrm{C}$. Then the mixture was supplemented with $1.5 \mathrm{M}\left(\mathrm{NH}_{4}\right)_{2} \mathrm{SO}_{4}$. The mixture was centrifuged $\left(3000 \times \mathrm{g}\right.$ for $35 \mathrm{~min}$ at $\left.4^{\circ} \mathrm{C}\right)$ before loading on a butylsepharose 6 Fast Flow column. The protein solution was eluted with $100 \mathrm{mM}$ Tris- $\mathrm{HCl}, \mathrm{pH} 7.2$, $10 \mathrm{mM} \beta$-mercaptoethanol. The fractions containing protein were further purified using a SEC column HiLoad 16/60 Superdex 75 prep grade (GE Healthcare, Chicago, IL, USA) previously equilibrated with $50 \mathrm{mM} \mathrm{KH}_{2} \mathrm{PO}_{4}, 50 \mathrm{mM} \mathrm{Na}_{2} \mathrm{HPO}_{4}, \mathrm{pH}$ 7.4, $150 \mathrm{mM} \mathrm{NaCl}, 5 \mathrm{mM} \beta$-mercaptoethanol. 


\subsection{Purification in Native Conditions of $M d m X$, wt-p53, and $p 53$}

The recombinant MdmX (18-111 aa) was cloned into pET46Ek/LIC vector (Novagen, Medison, WI, USA) and expressed in E. coli BL21 (DE3) (Invitrogen, Poland). The wt-p53 (1-321 aa) as well as its mutants were cloned into the pET23 vector (Novagen, Medison, WI, USA) and expressed in E. coli BL21 (DE3) RIL (Invitrogen, Poland). Cells were grown in LB medium $\left(100 \mu \mathrm{g} / \mathrm{mL}\right.$ ampicillin) at $37^{\circ} \mathrm{C}$ and induced with $1 \mathrm{mM}$ IPTG $\left(\mathrm{OD}_{600}\right.$ around 0.6-0.8). The protein expression was performed for an additional $12 \mathrm{~h}$ at $20^{\circ} \mathrm{C}$. Cells were harvested by centrifugation. The cell pellet was then resuspended in a lysis buffer $\left(50 \mathrm{mM} \mathrm{Na}_{2} \mathrm{HPO}_{4}, 300 \mathrm{mM} \mathrm{NaCl}, 10 \mathrm{mM}\right.$ imidazole $\mathrm{pH}$ 8.0) and sonicated as described before. After centrifugation at $60,000 \times g$ for $30 \mathrm{~min}$ at $4{ }^{\circ} \mathrm{C}$, the supernatant was loaded on the Ni-NTA column and incubated for $2 \mathrm{~h}$ at $4{ }^{\circ} \mathrm{C}$. Loaded protein was washed with buffer: $50 \mathrm{mM} \mathrm{Na}_{2} \mathrm{HPO}_{4}, 300$ $\mathrm{mM} \mathrm{NaCl}, 10 \mathrm{mM}$ imidazole $\mathrm{pH} 8.0$ to elute any unspecifically bound proteins. The target protein was eluted with buffer: $50 \mathrm{mM} \mathrm{NaH} \mathrm{PO}_{4}, 300 \mathrm{mM} \mathrm{NaCl}, 10 \mathrm{mM}$ imidazole, $\mathrm{pH}$ 8.0; relevant fractions were pooled, concentrated, and purified by gel filtration in PBS.

\subsection{Purification of Human wt-PD-1, PD-1 (N66A, Y68A, E135A, and N66AY68A), PD-L1, and PD-L1-Long}

The human wt-PD-1 (33-150 aa, C93S mutation) and its mutants (N66A, Y68A, E135A, and N66AY68A) were cloned into pET24d (Novagen, Medison, WI, USA), while recombinant PD-L1 (18-134 aa) and PD-L1-Long (19-238 aa) were cloned into pET-21b and pET-28a (Novagen, Medison, WI, USA), respectively. Each protein was expressed in E. coli BL21 (DE3) (New England Biolabs). Bacterial cultures were grown overnight at $37^{\circ} \mathrm{C}$ in LB or M9 minimal medium and induced at OD600 of ca. 0.8 with $1 \mathrm{mM}$ IPTG. Following inclusion, purification of bodies was performed using a previously described protocol [59]. Solubilized proteins were refolded by a drop-wise dilution into a solution containing $0.1 \mathrm{M}$ Tris $\mathrm{pH}$ 8.0, $0.4 \mathrm{M}$ L-arginine hydrochloride, $2 \mathrm{mM}$ EDTA, $5 \mathrm{mM}$ cystamine, and $0.5 \mathrm{mM}$ cysteamine (wt-PD-1 and PD-1 mutants) or $0.1 \mathrm{M}$ Tris pH 8.0, $1 \mathrm{M}$ L-arginine hydrochloride, $0.25 \mathrm{mM}$ oxidized glutathione, and $0.25 \mathrm{mM}$ reduced glutathione (PD-L1 and PD-L1-Long). Refolded proteins were next dialyzed $3 \times$ against a buffer containing $10 \mathrm{mM}$ Tris $\mathrm{pH} 8.0$ and $20 \mathrm{mM} \mathrm{NaCl}$ and purified using a SEC HiLoad 26/600 Superdex 75 column (GE Healthcare, Chicago, IL, USA) in $25 \mathrm{mM}$ sodium phosphate pH 6.4 with $100 \mathrm{mM} \mathrm{NaCl}$ for wt-PD-1 and PD-1 mutants or in PBS pH 7.4 for PD-L1 and PD-L1-Long.

\subsection{ITC Measurements}

All ITC experiments were performed on a Microcal iTC200 calorimeter according to the manufacturer's protocols. To compensate for the heat generated due to protein dilution, a separate experiment was performed in which a protein solution was injected into a sample chamber with a corresponding buffer. The resulting heat was then subtracted from the final signal as a background.

Data were fitted using $\mathrm{Chi}^{2}$ minimization for a model assuming a single set of sites to calculate the binding affinity KD using ORIGIN 7.0 (OriginLab Corporation One, Northampton, MA, USA). p53-wt and mutants with Mdm2 and MdmX titrations settings were as follow: 20 injections, $25^{\circ} \mathrm{C}$ cell temperature, $10 \mu \mathrm{cal} / \mathrm{s}$ reference power, $600 \mathrm{~s}$ initial delay, $0.012-0.030 \mathrm{mM}$ p53 cell concentration, $0.1-0.3 \mathrm{mM}$ of titrant ( $\mathrm{Mdm} 2$ or $\mathrm{MdmX}$ ) syringe concentration, and a stirring speed of $800 \mathrm{rpm}$. The first injection volume was $0.4 \mu \mathrm{L}$ with an injection time of $0.2 \mathrm{~s}$, while the rest were $2 \mu \mathrm{L}$ ( $4 \mathrm{~s}$ injection times). Gaps between injections were set at $150 \mathrm{~s}$, and data points were recorded every $5 \mathrm{~s}$. All experiments were performed in duplicate.

\subsection{Syntheses}

Nutlin-3a and compounds 1, 2, 3, and 4 were purchased. Compounds 5 and 6 were synthesized according to the methods described by Guzik et al. [57]. 


\subsection{Mutagenesis}

Site directed mutagenesis of $\mathrm{p} 53$ and PD- 1 were performed using PCR. The mutagenic primers for p53 (Supplementary Table S1) were designed for QuickChange Site-directed mutagenesis kit (Agilent Technologies, Stevens Creek Boulevard Santa Clara, CA, USA). Vectors pET28a with human p53 were used as templates. The mutagenic primers used for PD-1 (Supplementary Table S1) were designed using an inversed PCR approach. Vectors pET24d and pET21b with human PD-1, respectively, were used in the same manner.

\subsection{NMR Measurements}

Proteins were uniformly ${ }^{15} \mathrm{~N}$ labeled via expression in minimal medium with ${ }^{15} \mathrm{NH}_{4} \mathrm{Cl}$ as the sole nitrogen source. Then $10 \%(v / v)$ of $\mathrm{D}_{2} \mathrm{O}$ was added to the samples to provide lock signal. Spectra were recorded using a Bruker Avance III $600 \mathrm{MHz}$ spectrometer at $300 \mathrm{~K}$ equipped with the nitrogen cryo-probe head. By analyzing the line width (relaxation time) of well separated NMR signals, we approximated molecular weights of protein populations present in the sample [59]. During the experiment, the ${ }^{1} \mathrm{H}_{-}{ }^{15} \mathrm{~N}$ signals were monitored by the SOFAST HMQC (selective optimized flip-angle short-transient heteronuclear multiple quantum coherence) [60].

\subsection{MST Assay}

The binding affinities between PD-1 (or mutant) with PD-L1 were analyzed using the MST technique. PD-1 and its mutant were fluorescently labelled according the standard labeling protocol of the NanoTemper protein labeling kit RED-NHS (L001-NanoTemper Technologies, Munich, Germany). In MST experiments, the concentration of the labeled PD-1 and mutant was kept constant $(20 \mathrm{nM})$, while the unlabeled PD-L1 were serially diluted in MST buffer (50 mM Tris-HCl buffer, $\mathrm{pH}$ 7.6, $150 \mathrm{mM}$ $\mathrm{NaCl}, 10 \mathrm{mM} \mathrm{MgCl}$, and $0.05 \%$ Tween-20) from $416 \mathrm{nM}$ to $183 \mu \mathrm{M}$. Samples were premixed and incubated for $2 \mathrm{~h}$ at RT in the dark before loading into capillaries. Data processing is described in the legend of Supplementary Figure S11.

\subsection{Homogenous Time-Resolved Fluorescence (HTRF)}

The HTRF assay was performed using the certified Cis-Bio assay kit at $20 \mu \mathrm{L}$ final volume using their standard protocol as described by Musielak et al. [54]. Measurements were performed on individual dilution series to determine the half maximal inhibitory concentration $\left(\mathrm{IC}_{50}\right)$ of tested compounds. After mixing all components according to the Cis-Bio protocol, the plate was incubated for $2 \mathrm{~h}$ at RT. TR-FRET measurement was performed on the Tecan Spark 20M. Collected data was background subtracted on the negative control, normalized on the positive control, averaged, and fitted with the normalized Hill's equation to determine the $\mathrm{IC}_{50}$ value using Mathematica 12 (Wolfram, Oxfordshire, United Kingdom).

\subsection{Fluorescence Polarization Assay (FP)}

The FP competition assay is based on the displacement of p53 mutant peptide called P2 from the complex with $\mathrm{Mdm} 2 / \mathrm{X}$, as previously described [61]. All measurements were conducted on a Tecan Infinite ${ }^{2} 200$ PRO plate reader (Tecan Austria GmbH, Grödig, Austria). Buffer formulation was as follow: $50 \mathrm{mM} \mathrm{NaCl}, 10 \mathrm{mM}$ Tris pH 8.0, $1 \mathrm{mM}$ EDTA, 5\% DMSO. FP was determined at $\lambda=485 \mathrm{~nm}$ excitation and $\lambda=535 \mathrm{~nm}$ emission $15 \mathrm{~min}$ after mixing all assay components. All tests were performed using Corning black 96-well NBS assay plates (Corning, Corning, NY, USA) at room temperature.

\section{Conclusions}

Fragment screening is frequently the first step for the identification and development of molecules that modulate the activity of therapeutic targets. Numerous biophysical methods exist for the identification of fragment hits [62-65]. Among them, the NMR experiment is recognized as a highly 
robust technique for fragment screening against protein targets [6,8,66-68]. Here, we described a competition NMR experiment- $\mathrm{w}$-AIDA-NMR - that is sensitive to weak $\mu \mathrm{M}-\mathrm{mM}$ interactions and directly shows whether an antagonist releases proteins from their PPI interaction. We believe that $\mathrm{w}$-AIDA-NMR is a valuable complement to the renowned binary ligand-protein SAR-by-NMR assay $[6,66,67]$ but also to the saturation transfer difference (STD) NMR experiment. For the STD, AIDA-NMR avoids weak points of that experiment as the AIDA-NMR offers checking for compound aggregation and protein instability, two situations leading to false positives. Moreover, by introducing the mutations into a non-binding partner, w-AIDA-NMR is performed under physiological conditions as the target protein/ligand interface is not compromised. This was further validated using the native PD-1/PD-L1-Long complex that was dissociated by compounds 5 and $\mathbf{6}$ in a similar manner as the (N66A)PD-1/PD-L1, therefore indicating that the point mutation at the interface of the small molecule non-binding partner indeed does not affect a subsequent target protein/ligand complex. Our NMR results presented here confirmed unambiguously that small-molecule compounds that are able to dissociate the complex between mutant-p53/Mdm2, mutant-p53/MdmX, and the mutated PD-1 and PD-L1 could be fished out, and we could estimate the dissociation constant of the targeted protein/fragment interaction. For the PD-1/PD-L1 small-molecule inhibitor BMS-1166, we could determine that the minimal fragment of BMS-1166 responsible for the PD-L1 binding is fragment 5.

Supplementary Materials: The following are available online, Table S1. Sequence of primers used for mutagenesis of p53 and PD-1; Figure S1. Stereo view of (a) the Mdm2 complex with p53, (b) the MdmX complex with p53 and (c) the PD-L1 complex with PD-1. The complexes interfaces are colored blue. Partner amino acid residues that were mutated for this publication are colored red, native crucial residues for the interactions are colored green, while other important residues at the interface are colored purple.; Figure S2. Results of the ITC. Binding of p53-wt (1-321) to Mdm2 (a) and MdmX (b).; Figure S3. Results of the ITC. Binding of p53-wt (1-321) mutants: L22A (a), L22I (b) and L22V (c) to Mdm2.; Figure S4. Results of the ITC. Binding of p53-wt (1-321) mutants: L22A (a), L22I (b) and L22V (c) to MdmX.; Figure S5. Results of the ITC. Binding of p53-wt (1-321) mutants: L26I (a) and L26V (b) to Mdm2.; Figure S6. Results of the ITC. Binding of p53-wt (1-321) mutants: L26I (a) and L26V (b) to MdmX.; Figure S7. Results of the ITC. Binding of different L22VL26V (a) and L22IL26V mutants (b) to Mdm2.; Figure S8. Results of the ITC. Binding of different L22VL26V (a) and L22IL26V mutants (b) to MdmX.; Figure S9. A 1D NMR

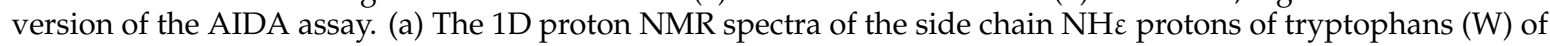
free $\mathrm{p} 53$ (residues 1-321). The N-terminal domain of p53 contains three tryptophan residues: W23, W53, and W91. The side chains of W23 and W53 give rise to sharp lines, because the very N-terminal segment of p53 comprising residues 1-73 has been shown to be very flexible. (b) Upon forming the complex with Mdm2 (residues 1-125), the signal of W23 disappears. This is because W23, together with the p53 residues 17 to 26, comprise the primary binding site for Mdm2. Upon binding, these residues participate in a well-defined structure of a large p53-Mdm2 complex, whereas W53 is still not structured when p53 is bound to Mdm2. Thus, the observed 1/T2 transverse relaxation rate of the bound W23 in the complexes increases thus significantly and broadening of NMR resonances results in the disappearance of this signal in the spectra. (c) Disruption of the Mdm2-p53 interaction results in the release of free p53 and the recovery of the W23p53 NHz signal. The height of $\mathrm{W} 23$ peak corresponds to the fraction of free p53 and thus, when total concentrations of the complex and the antagonist are known, the KD of the Mdm2-antagonist interaction can be determined from a single competition experiment. (d) A weak inhibitor does not dissociate the complex.; Figure S10. Determination of inhibition constants Ki from FP assay for Mdm2 protein (middle row) and MdmX (bottom row). Top row is the positive control Nutlin-3a. Data is an average of 2 dilution series fitted with the based on the mass balance relationships as described.; Figure S11. Human PD-1 (hPD-1) is a protein of 288 amino acids. The extracellular domain of hPD-1 is 150 amino acid long (amino acids 21-170, 1-20 constitutes the signal peptide). The transmembrane domain is short (amino acids 171-191) and is followed by a cytoplasmic domain of 97 residues (positions 192-288).; Figure S12. Determination of the KDs for PD-1/PD-L1 complex (blue)-8.0 $\mu \mathrm{M}$, (N66A)PD-1/PD-L1 complex (red)—over $100 \mu \mathrm{M}$ and PD-1/PD-L1-Long complex (green) - ca. $51 \mu \mathrm{M}$ using MST.; Figure S13. The interactions between PD-L1 (gray surface) and selected residues from PD-1 involved in complex formation depicted as blue sticks (PDB ID:4ZQK). (a) The inset presents N66A mutation where the hydrogen bond between the side chain of Asn66 and the carbonyl main-chain oxygen of LAla121is abolished if Asn66 is mutated to alanine (yellow overlay). (b) overlay of the PD-L1 amino acids involved in complex formation from various PDB high resolution crystal structures of PD-1: blue from native complex (PDB ID:4ZQK), green from high affinity PD-1 mutant (5isu) and purple from mPD-1 complex (3SBW).; Figure S14. The comparison of melting temperatures of wt-PD-1 (black) and (N66A)PD-1 mutant (red). Data represented as a first derivative of the fluorescence ratio at $350 / 330 \mathrm{~nm}$ dependence on the temperature.; Figure S15. The smallest active fragments of BMS-1166 and BMS-1166 compound tested for the interaction with PD-L1.; Figure S16. 1H-15N HMQC spectra of PD-1 (a), the complex of PD-1/PD-L1 (b), the complex of PD-1/PD-L1 with 5 (c) and $6(\mathrm{~d}$ ) in the molar ratio 1:1, and the complex of PD-1/PD-L1 with 5 and BMS-1166 (as a positive control to show that the complex can be dissociated) in the molar ratio 1:1:1 (e).; Figure S17. The aliphatic part of $1 \mathrm{H}$ NMR spectra of PD-1 (blue), PD-L1 (red), the complex of PD-1/PD-L1 (green), the complex of PD-1/PD-L1 with 5 
(purple) and 6 (yellow) in the molar ratio 1:1, the complex of PD-1/PD-L1 with 5 and BMS-1166 in the molar ratio 1:1:1 (orange).; Figure S18. The aliphatic part of 1H NMR spectra of (N66A)PD-1 (blue), PD-L1 (red), the complex of (N66A)PD-1/PD-L1 (green), the complex of (N66A)PD-1/PD-L1 with 5 (purple) and 6 (yellow) in the molar ratio 1:1, the complex of (N66A)PD-1/PD-L1 with 6 and BMS-1166 in the molar ratio 1:1:1 (orange).; Figure S19. The determination of the inhibition constant IC50 for compound 5 (a) and compound 6 (b) using HTRF. Raw data was fitted with Hill's model. The goodness of fit is represented in reduced Chi^2.; Figure S20. 1H-15N HMQC spectra of the 15N PD-1. (a) Wt-PD-1. (b) The complex of wt-PD-1/wt-PD-L1-Long. (c) The complex of wt-PD-1/wt-PD-L1-Long with 5 in the molar ratio 1:1 of the protein complex and the compound. (d) The complex of wt-PD-1/wt-PD-L1-Long with 5 and BMS-1166 in the molar ratio 1:1:1 of the protein complex and the compounds. (e) The aliphatic part of 1H NMR spectra of wt-PD-1 (blue), wt-PD-L1-Long (red), the complex of wt-PD-1/wt-PD-L1-Long (green), the complex of wt-PD-1/wt-PD-L1-Long with 5 (purple) in the molar ratio protein to the compound 1:1, and the complex of wt-PD-1/wt-PD-L1-Long with 5 and BMS-1166 (as a positive control to show that the complex can be dissociated) in the molar ratio 1:1:1 of the protein and the compounds (yellow).

Author Contributions: T.A.H., W.J., and B.M. conceived the study and designed experiments. B.M., W.J., I.R., D.S., K.M.-M., and J.P. carried out the experimental work and data analysis. B.M. and T.H. wrote the manuscript. All authors contributed to discussions and revisions of the manuscript. All authors have read and agreed to the published version of the manuscript.

Acknowledgments: This research has been supported by the Grants Symphony UMO-2014/12/W/NZ1/00457 and Maestro 2017/26/A/ST5/00572 (to T.A.H.) from the National Science Centre, Poland. We would like to thank Katarzyna Guzik for an excellent support in organic syntheses.

Conflicts of Interest: The authors declare no competing interests.

\section{References}

1. Meyer, B.; Peters, T. NMR Spectroscopy Techniques for Screening and Identifying Ligand Binding to Protein Receptors. Angew. Chemie Int. Ed. 2003, 42, 864-890. [CrossRef] [PubMed]

2. Hajduk, P.J.; Greer, J. A decade of fragment-based drug design: strategic advances and lessons learned. Nat. Rev. Drug Discov. 2007, 6, 211-219. [CrossRef] [PubMed]

3. Perry, E.; Mills, J.J.; Zhao, B.; Wang, F.; Sun, Q.; Christov, P.P.; Tarr, J.C.; Rietz, T.A.; Olejniczak, E.T.; Lee, T.; et al. Fragment-based screening of programmed death ligand 1 (PD-L1). Bioorg. Med. Chem. Lett. 2019, 29, 786-790. [CrossRef] [PubMed]

4. Fielding, L. NMR Methods for the Determination of Protein- Ligand Dissociation Constants. Curr. Top. Med. Chem. 2003, 3, 39-53. [CrossRef] [PubMed]

5. Shortridge, M.D.; Hage, D.S.; Harbison, G.S.; Powers, R. Estimating Protein-Ligand Binding Affinity Using High-Throughput Screening by NMR. J. Comb. Chem. 2008, 10, 948-958. [CrossRef]

6. Shuker, S.B.; Hajduk, P.J.; Meadows, R.P.; Fesik, S.W. Discovering High-Affinity Ligands for Proteins: SAR by NMR. Science 1996, 274, 1531-1534. [CrossRef]

7. Babaoglu, K.; Shoichet, B.K. Deconstructing fragment-based inhibitor discovery. Nat. Chem. Biol. 2006, 2, 720-723. [CrossRef] [PubMed]

8. Dalvit, C. NMR methods in fragment screening: theory and a comparison with other biophysical techniques. Drug Discov. Today 2009, 14, 1051-1057. [CrossRef] [PubMed]

9. D'Silva, L.; Ozdowy, P.; Krajewski, M.; Rothweiler, U.; Singh, M.; Holak, T.A. Monitoring the Effects of Antagonists on Protein-Protein Interactions with NMR Spectroscopy. J. Am. Chem. Soc. 2005, 127, 13220-13226. [CrossRef] [PubMed]

10. Krajewski, M.; Rothweiler, U.; D'Silva, L.; Majumdar, S.; Klein, C.; Holak, T.A. An NMR-Based Antagonist Induced Dissociation Assay for Targeting the Ligand-Protein and Protein-Protein Interactions in Competition Binding Experiments. J. Med. Chem. 2007, 50, 4382-4387. [CrossRef]

11. Krajewski, M.; Ozdowy, P.; D'Silva, L.; Rothweiler, U.; Holak, T.A. NMR indicates that the small molecule RITA does not block p53-MDM2 binding in vitro. Nat. Med. 2005, 11, 1135-1136. [CrossRef] [PubMed]

12. Rothweiler, U.; Czarna, A.; Krajewski, M.; Ciombor, J.; Kalinski, C.; Khazak, V.; Ross, G.; Skobeleva, N.; Weber, L.; Holak, T.A. Isoquinolin-1-one Inhibitors of the MDM2-p53 Interaction. ChemMedChem 2008, 3, 1118-1128. [CrossRef] [PubMed]

13. Bista, M.; Kowalska, K.; Janczyk, W.; Dömling, A.; Holak, T.A. Robust NMR Screening for Lead Compounds Using Tryptophan-Containing Proteins. J. Am. Chem. Soc. 2009, 131, 7500-7501. [CrossRef] 
14. Pellecchia, M.; Bertini, I.; Cowburn, D.; Dalvit, C.; Giralt, E.; Jahnke, W.; James, T.L.; Homans, S.W.; Kessler, H.; Luchinat, C.; et al. Perspectives on NMR in drug discovery: a technique comes of age. Nat. Rev. Drug Discov. 2008, 7, 738-745. [CrossRef] [PubMed]

15. Brown, C.J.; Lain, S.; Verma, C.S.; Fersht, A.R.; Lane, D.P. Awakening guardian angels: drugging the p53 pathway. Nat. Rev. Cancer 2009, 9, 862-873. [CrossRef] [PubMed]

16. Cheok, C.F.; Verma, C.S.; Baselga, J.; Lane, D.P. Translating p53 into the clinic. Nat. Rev. Clin. Oncol. 2011, 8 , 25-37. [CrossRef] [PubMed]

17. Sharma, P.; Allison, J.P. Immune Checkpoint Targeting in Cancer Therapy: Toward Combination Strategies with Curative Potential. Cell 2015, 161, 205-214. [CrossRef] [PubMed]

18. Kelly, P.N. The Cancer Immunotherapy Revolution. Science 2018, 359, 1344-1345. [CrossRef]

19. Khoo, K.H.; Verma, C.S.; Lane, D.P. Drugging the p53 pathway: understanding the route to clinical efficacy. Nat. Rev. Drug Discov. 2014, 13, 217-236. [CrossRef]

20. Wade, M.; Li, Y.-C.; Wahl, G.M. MDM2, MDMX and p53 in oncogenesis and cancer therapy. Nat. Rev. Cancer 2013, 13, 83-96. [CrossRef]

21. Vogelstein, B.; Lane, D.; Levine, A.J. Surfing the p53 network. Nature 2000, 408, 307-310. [CrossRef]

22. Vousden, K.H.; Lu, X. Live or let die: the cell's response to p53. Nat. Rev. Cancer 2002, 2, 594-604. [CrossRef] [PubMed]

23. Wherry, E.J. T cell exhaustion. Nat. Immunol. 2011, 12, 492-499. [CrossRef] [PubMed]

24. Riley, J.L. PD-1 signaling in primary T cells. Immunol. Rev. 2009, 229, 114-125. [CrossRef]

25. Schalper, K.A.; Brown, J.; Carvajal-Hausdorf, D.; McLaughlin, J.; Velcheti, V.; Syrigos, K.N.; Herbst, R.S.; Rimm, D.L. Objective Measurement and Clinical Significance of TILs in Non-Small Cell Lung Cancer. JNCI J. Natl. Cancer Inst. 2015, 107. [CrossRef] [PubMed]

26. Khalil, D.N.; Smith, E.L.; Brentjens, R.J.; Wolchok, J.D. The future of cancer treatment: immunomodulation, CARs and combination immunotherapy. Nat. Rev. Clin. Oncol. 2016, 13, 273-290. [CrossRef] [PubMed]

27. Ribas, A.; Wolchok, J.D. Cancer immunotherapy using checkpoint blockade. Science 2018, 359, $1350-1355$. [CrossRef]

28. Mahoney, K.M.; Rennert, P.D.; Freeman, G.J. Combination cancer immunotherapy and new immunomodulatory targets. Nat. Rev. Drug Discov. 2015, 14, 561-584. [CrossRef]

29. Topalian, S.L.; Drake, C.G.; Pardoll, D.M. Immune Checkpoint Blockade: A Common Denominator Approach to Cancer Therapy. Cancer Cell 2015, 27, 450-461. [CrossRef]

30. Dömling, A.; Holak, T.A. Programmed Death-1: Therapeutic Success after More than 100 Years of Cancer Immunotherapy. Angew. Chemie Int. Ed. 2014, 53, 2286-2288. [CrossRef]

31. Hoos, A. Development of immuno-oncology drugs - from CTLA4 to PD1 to the next generations. Nat. Rev. Drug Discov. 2016, 15, 235-247. [CrossRef]

32. Altmann, D.M. A Nobel Prize-worthy pursuit: cancer immunology and harnessing immunity to tumour neoantigens. Immunology 2018, 155, 283-284. [CrossRef]

33. Ledford, H.; Else, H.; Warren, M. Cancer immunologists scoop medicine Nobel prize. Nature 2018, 562, $20-21$. [CrossRef] [PubMed]

34. Cheng, X.; Veverka, V.; Radhakrishnan, A.; Waters, L.C.; Muskett, F.W.; Morgan, S.H.; Huo, J.; Yu, C.; Evans, E.J.; Leslie, A.J.; et al. Structure and Interactions of the Human Programmed Cell Death 1 Receptor. J. Biol. Chem. 2013, 288, 11771-11785. [CrossRef] [PubMed]

35. Schon, O.; Friedler, A.; Bycroft, M.; Freund, S.M.V.; Fersht, A.R. Molecular Mechanism of the Interaction between MDM2 and p53. J. Mol. Biol. 2002, 323, 491-501. [CrossRef]

36. Edlund, K.; Larsson, O.; Ameur, A.; Bunikis, I.; Gyllensten, U.; Leroy, B.; Sundstrom, M.; Micke, P.; Botling, J.; Soussi, T. Data-driven unbiased curation of the TP53 tumor suppressor gene mutation database and validation by ultradeep sequencing of human tumors. Proc. Natl. Acad. Sci. 2012, 109, 9551-9556. [CrossRef] [PubMed]

37. The TP53 Website - The TP53 Web Site. Available online: http://p53.fr/ (accessed on 8 June 2020).

38. Kussie, P.H.; Gorina, S.; Marechal, V.; Elenbaas, B.; Moreau, J.; Levine, A.J.; Pavletich, N.P. Structure of the MDM2 Oncoprotein Bound to the p53 Tumor Suppressor Transactivation Domain. Science 1996, 274, 948-953. [CrossRef]

39. Stoll, R.; Renner, C.; Hansen, S.; Palme, S.; Klein, C.; Belling, A.; Zeslawski, W.; Kamionka, M.; Rehm, T.; Mühlhahn, P.; et al. Chalcone Derivatives Antagonize Interactions between the Human Oncoprotein MDM2 and $\mathrm{p}^{+}{ }^{\dagger}$. Biochemistry 2001, 40, 336-344. [CrossRef] 
40. Popowicz, G.; Czarna, A.; Holak, T. Structure of the human Mdmx protein bound to the p53 tumor suppressor transactivation domain. Cell Cycle 2008, 7, 2441-2443. [CrossRef]

41. Popowicz, G.M.; Czarna, A.; Rothweiler, U.; Szwagierczak, A.; Krajewski, M.; Weber, L.; Holak, T.A. Molecular Basis for the Inhibition of p53 by Mdmx. Cell Cycle 2007, 6, 2386-2392. [CrossRef]

42. Skalniak, L.; Surmiak, E.; Holak, T.A. A therapeutic patent overview of MDM2/X-targeted therapies (2014-2018). Expert Opin. Ther. Pat. 2019, 29, 151-170. [CrossRef]

43. Popowicz, G.M.; Dömling, A.; Holak, T.A. The Structure-Based Design of Mdm2/Mdmx-p53 Inhibitors Gets Serious. Angew. Chemie Int. Ed. 2011, 50, 2680-2688. [CrossRef] [PubMed]

44. Zak, K.; Pecak, A.; Rys, B.; Wladyka, B.; Dömling, A.; Weber, L.; Holak, T.A.; Dubin, G. Mdm2 and MdmX inhibitors for the treatment of cancer: A patent review (2011-present). Expert Opin. Ther. Pat. 2013, 23, 425-448. [CrossRef] [PubMed]

45. Carneiro, B.A.; El-Deiry, W.S. Targeting apoptosis in cancer therapy. Nat. Rev. Clin. Oncol. 2020. [CrossRef]

46. Wang, S.; Zhao, Y.; Aguilar, A.; Bernard, D.; Yang, C.-Y. Targeting the MDM2-p53 Protein-Protein Interaction for New Cancer Therapy: Progress and Challenges. Cold Spring Harb. Perspect. Med. 2017, 7, a026245. [CrossRef] [PubMed]

47. Vassilev, L.T. In Vivo Activation of the p53 Pathway by Small-Molecule Antagonists of MDM2. Science 2004, 303, 844-848. [CrossRef]

48. Kocik, J.; Machula, M.; Wisniewska, A.; Surmiak, E.; Holak, T.A.; Skalniak, L. Helping the Released Guardian: Drug Combinations for Supporting the Anticancer Activity of HDM2 (MDM2) Antagonists. Cancers (Basel). 2019, 11, 1014. [CrossRef]

49. Huang, Y.; Wolf, S.; Koes, D.; Popowicz, G.M.; Camacho, C.J.; Holak, T.A.; Dömling, A. Exhaustive Fluorine Scanning toward Potent p53-Mdm2 Antagonists. ChemMedChem 2012, 7, 49-52. [CrossRef]

50. Popowicz, G.M.; Czarna, A.; Wolf, S.; Wang, K.; Wang, W.; Dömling, A.; Holak, T.A. Structures of low molecular weight inhibitors bound to MDMX and MDM2 reveal new approaches for p53-MDMX/MDM2 antagonist drug discovery. Cell Cycle 2010, 9, 1104-1111. [CrossRef]

51. Rothweiler, U.; Czarna, A.; Weber, L.; Popowicz, G.M.; Brongel, K.; Kowalska, K.; Orth, M.; Stemmann, O.; Holak, T.A. NMR screening for lead compounds using tryptophan-mutated proteins. J. Med. Chem. 2008. [CrossRef]

52. Zak, K.M.; Kitel, R.; Przetocka, S.; Golik, P.; Guzik, K.; Musielak, B.; Dömling, A.; Dubin, G.; Holak, T.A. Structure of the Complex of Human Programmed Death 1, PD-1, and Its Ligand PD-L1. Structure 2015, 23, 2341-2348. [CrossRef] [PubMed]

53. Guzik, K.; Tomala, M.; Muszak, D.; Konieczny, M.; Hec, A.; Błaszkiewicz, U.; Pustuła, M.; Butera, R.; Dömling, A.; Holak, T.A. Development of the Inhibitors That Target the PD-1/PD-L1 Interaction-A Brief Look at Progress on Small Molecules, Peptides and Macrocycles. Molecules 2019, 24, 2071. [CrossRef] [PubMed]

54. Musielak, B.; Kocik, J.; Skalniak, L.; Magiera-Mularz, K.; Sala, D.; Czub, M.; Stec, M.; Siedlar, M.; Holak, T.A.; Plewka, J. CA-170_A Potent Small-Molecule PD-L1 Inhibitor or Not? Molecules 2019, 24, 2804. [CrossRef] [PubMed]

55. Chupak, L.S.; Zheng, X. Compounds Useful as Immunomo-Dulators. 2015, WO/2015/03.

56. Chupak, L.S.; Ding, M.; Martin, S.W.; Zheng, X.; Hewawasam, P.; Connolly, T.P.; Xu, N.; Yeung, K.-S.; Zhu, J.; Langley, D.R.; et al. Compounds Useful as Immunomodulators. 2015, WO/2015/16.

57. Guzik, K.; Zak, K.M.; Grudnik, P.; Magiera, K.; Musielak, B.; Törner, R.; Skalniak, L.; Dömling, A.; Dubin, G.; Holak, T.A. Small-Molecule Inhibitors of the Programmed Cell Death-1/Programmed Death-Ligand 1 (PD-1/PD-L1) Interaction via Transiently Induced Protein States and Dimerization of PD-L1. J. Med. Chem. 2017, 60, 5857-5867. [CrossRef] [PubMed]

58. Zak, K.M.; Grudnik, P.; Guzik, K.; Zieba, B.J.; Musielak, B.; Dömling, A.; Dubin, G.; Holak, T.A. Structural basis for small molecule targeting of the programmed death ligand 1 (PD-L1). Oncotarget 2016, 7, 30323-30335. [CrossRef]

59. Skalniak, L.; Zak, K.M.; Guzik, K.; Magiera, K.; Musielak, B.; Pachota, M.; Szelazek, B.; Kocik, J.; Grudnik, P.; Tomala, M.; et al. Small-molecule inhibitors of PD-1/PD-L1 immune checkpoint alleviate the PD-L1-induced exhaustion of T-cells. Oncotarget 2017, 8, 72167-72181. [CrossRef] 
60. Schanda, P.; Kupče, Ē.; Brutscher, B. SOFAST-HMQC Experiments for Recording Two-dimensional Deteronuclear Correlation Spectra of Proteins within a Few Seconds. J. Biomol. NMR 2005, 33, 199-211. [CrossRef]

61. Czarna, A.; Popowicz, G.M.; Pecak, A.; Wolf, S.; Dubin, G.; Holak, T.A. High affinity interaction of the p53 peptide-analogue with human Mdm2 and Mdmx. Cell Cycle 2009, 8, 1176-1184. [CrossRef]

62. Erlanson, D.A. Introduction to fragment-based drug discovery. Top. Curr. Chem. 2012, 1-32.

63. Chen, H.; Zhou, X.; Wang, A.; Zheng, Y.; Gao, Y.; Zhou, J. Evolutions in fragment-based drug design: the deconstruction-reconstruction approach. Drug Discov. Today 2015, 20, 105-113. [CrossRef]

64. Erlanson, D.A.; Davis, B.J.; Jahnke, W. Fragment-Based Drug Discovery: Advancing Fragments in the Absence of Crystal Structures. Cell Chem. Biol. 2019, 26, 9-15. [CrossRef] [PubMed]

65. Erlanson, D.A.; de Esch, I.J.P.; Jahnke, W.; Johnson, C.N.; Mortenson, P.N. Fragment-to-Lead Medicinal Chemistry Publications in 2018. J. Med. Chem. 2020, 63, 4430-4444. [CrossRef] [PubMed]

66. Hajduk, P.J.; Sheppard, G.; Nettesheim, D.G.; Olejniczak, E.T.; Shuker, S.B.; Meadows, R.P.; Steinman, D.H.; Carrera, G.M.; Marcotte, P.A.; Severin, J.; et al. Discovery of Potent Nonpeptide Inhibitors of Stromelysin Using SAR by NMR. J. Am. Chem. Soc. 1997, 119, 5818-5827. [CrossRef]

67. Harner, M.J.; Frank, A.O.; Fesik, S.W. Fragment-based drug discovery using NMR spectroscopy. J. Biomol. NMR 2013, 56, 65-75. [CrossRef]

68. Barile, E.; Pellecchia, M. NMR-Based Approaches for the Identification and Optimization of Inhibitors of Protein-Protein Interactions. Chem. Rev. 2014, 114, 4749-4763. [CrossRef]

Sample Availability: Samples of the compounds are available upon reasonable request from the authors.

(C) 2020 by the authors. Licensee MDPI, Basel, Switzerland. This article is an open access article distributed under the terms and conditions of the Creative Commons Attribution (CC BY) license (http://creativecommons.org/licenses/by/4.0/). 